Article

\title{
Future anxiety in students of communication and Islamic broadcasting program: The correlation with resilience
}

\author{
Hana Mutia, ${ }^{1}$ Giur Hargiana ${ }^{2}$ \\ ${ }^{1}$ Faculty of Nursing, Universitas Indonesia, Depok, West Java; ${ }^{2}$ Department of Mental Health Nursing, Faculty \\ of Nursing, Universitas Indonesia, Depok, West Java, Indonesia
}

\begin{abstract}
Background: Anxiety becomes a mental health problem that students experience most frequently. One of the anxiety disorders in students is future anxiety. A high level of unemployment becomes the most significant stressor of this anxiety. In 2019, the department of communication became the department with the highest unemployment rate in the world. The students at Communication and Islamic Broadcasting Department feel this phenomenon and find difficulties in finding a job. This condition triggers the students' concerns about the future. In this case, future anxiety can be influenced by one of the protective factors, namely resilience. This study aims to identify the correlation between resilience and future anxiety of the Communication and Islamic Broadcasting Department's students.

Design and Methods: This study was conducted by employing a cross-sectional design and involving students at the Communication and Islamic Broadcasting Department $(n=238)$ of Universitas Ibn Khaldun, Bogor. This study used the ConnorDavidson Resilience Scale 10 questionnaire to measure the resilience and Future Anxiety Scale to measure future anxiety. Meanwhile, the bivariate analysis between resilience and future anxiety was conducted by employing the Pearson productmoment correlation.

Results: This reveals a negative correlation between resilience and future anxiety $(-0.379)$ with a moderate correlation.

Conclusions: This study recommends several efforts to increase resilience for stress management, possibly guided by nurses. Moreover, higher education institutions can facilitate students by providing counseling and training in time management, enhancing adaptive coping, and developing the alumni association as media of future planning discussion for students.
\end{abstract}

\section{Introduction}

Mental health is one of human's basic needs, and if it is not fulfilled, it will create health problems. One of the mental health problems that society frequently suffers from is anxiety. The 2018 Basic Health Research survey reveals that the prevalence of mental-emotional disorders indicated by symptoms of depression and anxiety in Indonesia at the age of 15 years and over increased by $3.8 \%$ than that in $2013 .{ }^{1}$ Anxiety is mostly suffered by the early adulthood age group. Anxiety becomes the biggest psychological problem of university students for $41.6 \% .^{2}$ The anxiety occurs because the students are responsible for achieving the goals of education and occupation and are worried about their unpredictable future. ${ }^{3}$

Future anxiety is a fear of events in the future and feeling that dangerous or harmful changes will occur in the future. ${ }^{4}$ Future anxiety will appear on an individual at the age of twenty because they start to get jobs and have a family. The data of the Central Bureau of Statistics report that unemployed graduates in Indonesia increased by 1.26 in 2019. ${ }^{5}$ Furthermore, the COVID-19 pandemic brings significant impacts on employment. The National Development Planning Agency estimates that the number of unemployed will increase by up to $8.1-9.2 \%$ due to the 2020 pandemic. ${ }^{6}$

The 2019 communication study program became a study program with the highest number of unemployed graduates. ${ }^{7}$ A similar phenomenon is also encountered by students of Communication and Islamic Broadcasting Department of Universitas Ibn Khaldun, Bogor. The previous studies reveal that the graduates of Communication and Islamic Broadcasting Department of Universitas Ibn Khaldun, Bogor find difficulties in finding appropriate jobs, and many of them do not have jobs that are suitable for their expertise. Moreover, some of the students think that they are not sure about their department and consider that Islamic journalism has narrower perspectives than general journalism. Thus, they are worried that they will have limited job opportunities. Usman, Bustami, Setiana and Hayatullah discover that Communication and Islamic Broadcasting Department is less famous in public; thus, its graduates find difficulties in a global competition to get a job. ${ }^{8}$ The existing factors encourage students of the Communication and Islamic Broadcasting Department to

Significance for public health

Future anxiety occurs in students. The devastating impacts of future anxiety can interfere with a student's daily life and even lead to the risk of suicide. Therefore, to minimize the consequences, it is necessary to ascertain a factor, namely resilience, that triggers students to survive difficult situations. The result of this study indicates a significantly negative relationship between resilience and future anxiety. This result is beneficial as a basis for developing strategies to increase resilience for the community's health. Therefore, the students' future anxiety can decrease. The authors have suggested the procurement of a health education program in training in stress management for students. Moreover, the authors have proposed the procurement of time management counseling, the enhancement of adaptive coping, and the development of the alumni association as a media of future planning discussion for students. 
experience future anxiety.

Future anxiety can continuously become a bigger problem. The impacts of anxiety on students are the decrease in memory ability, low self-adjustment at the campus, poor academic performance, and dropout. ${ }^{9}$ Meanwhile, continuous anxiety and depression can increase the risk of suicide. ${ }^{10}$ It is reported that 1500 people commit suicide per day in Indonesia. ${ }^{11}$ Anxiety can be priorly avoided by recognizing factors that can affect humans' ways to respond to stressors to minimize these impacts. One of these factors is resilience. $^{12}$

Resilience is the ability to maintain psychological functions under challenging situations. ${ }^{13}$ A resilient person can achieve, maintain, or restore levels of mental health after experiencing a significant event of trauma, grief, or stress. In this case, resilience can help individuals have a better adaptation process to avoid future anxiety. However, there has been no research investigating resilience and future anxiety.

Based on this phenomenon, the researchers attempt to investigate the correlation between resilience and future anxiety in students of the Communication and Islamic Broadcasting Progam. This study considers that the Communication and Islamic Broadcasting Department is the department with the highest number of unemployed graduates. Furthermore, this study finds that the previous research results reveal that the graduates of the Communication and Islamic Broadcasting Department of Islam Universitas Ibn Khaldun Bogor have the anxiety to encounter their future. Based on these two major reasons, this research formulates a research question "is there any correlation between resilience and future anxiety in students of the Communication and Islamic Broadcasting Department?'

\section{Design and Methods}

The category of this research was quantitative research with a cross-sectional design. The research was approved by The Ethics Committee of Faculty of Nursing, Universitas Indonesia, with number SK-111/UN2.F12.D1.2.1/ETIK2020 on March 11, 2020. This study was conducted online by involving 251 students of the Communication and Islamic Broadcasting Program, Universitas Ibn Khaldun, Bogor. This study employed a total sampling method involving 238 final samples. The data were collected through an online technique due to the COVID-19 pandemic in Indonesia.

The data collection instruments were a questionnaire that consists of the respondents' characteristics, questioner of ConnorDavidson Resilience Scale 10 (CD-RISC 10), and the questioner of the Future Anxiety Scale (FAS). The CD-RISC 10 was a modified instrument of the Campbell-Sills and Stein, who created a short version of the CD-RISC 25 . The CD-RISC 10 consisted of ten questions with $\alpha=0.853$ and $r=>0.2 .{ }^{14}$ Meanwhile, FAS was created by Zaleski (1996) and modified by Nadira (2013) to be 16 questions with $\alpha=0.902$ dan $r=>0.2$ to measure future anxiety. ${ }^{15}$

The collected data were then processed by employing a computer data processing application. The data were then analyzed by using univariate analysis with proportion test for gender, academic year, and marital status and with central tendency test for variables of age, resilience, and anxiety of facing the future. Furthermore, this research employed bivariate analysis with the Pearson product-moment correlation test (two-tailed) to investigate the correlation between resilience and future anxiety. The hypothesis (Ha) of this reading stated that there was a relationship between resilience and the future anxiety experienced by the Communication and Islamic Broadcasting study program of Universitas Ibn Khaldun, Bogor.

\section{Results}

This research reveals that the respondents' average age is 20.03 years (95\% CI: 19.84-20.22), with a standard deviation of is 1.522 years. The gender of the students in this study was dominated by 121 male students $(50.8 \%)$. The majority of the students are students of class 2019 (42\%) and unmarried (98.3\%).

The description of the respondents' resilience was measured using the CD-RISC 10 questionnaire, and the numerical results were analyzed using the central tendency. The description of the resilience of the students of the Communication and Islamic Broadcasting Program of Universitas Ibn Khaldun is discovered by examining mean values, standard deviations, minimum values, and maximum values. The analysis of the respondents' resilience is presented in Table 1.

In the resilience variable, the mean values were employed in the presentation of data because the data distribution was normal. This result was proven by a bell curve and $p$-value $<0.05$ in the Kolmogorov-Smirnov test. Based on table 1, the result of this study reveals that the average resilience of the Communication and Islamic Broadcasting Department students of Universitas Ibn Khaldun is 38.37 (95\% CI: $37.61-39.13)$, with the standard of deviation is 5.956. These scores are categorized in a moderate level of resilience.

Meanwhile, the variable of future anxiety was tested using the central tendency test to determine the description of future anxiety of students of the Communication and Islamic Broadcasting Study Program of Universitas Ibn Khaldun. The mean values are presented in tables because the data distribution is normal with bell curves, and the Kolmogorov-Smirnov test signified p-value $<0.05$. The mean values, standard deviation, minimum values, and maximum values in future anxiety variables are presented in Table 2.

Table 2 shows that the average score of future anxiety of Communication and Islamic Broadcasting Department students of Universitas Ibn Khaldun is 38.08 (95\% CI: 35.33 - 40.84), with the standard deviation is 21.580 . These average scores are categorized in a moderate level of resilience.

Table 3 shows $\mathrm{p}<0.01$, and it indicates a correlation between resilience and future anxiety of Communication and Islamic

Table 1. Description of resilience of Communication and Islamic Broadcasting Department's students at Universitas Ibn Khaldun, Bogor ( $\mathbf{n}=238)$.

\begin{tabular}{lcccc} 
Variable & Mean & SD & Min-Max & $95 \%$ CI \\
Resilience & 38.37 & 5.956 & $11-50$ & $37.61-39.13$ \\
\hline
\end{tabular}

Table 2. Description of future anxiety of Communication and Islamic Broadcasting Department's students at Universitas Ibn Khaldun, Bogor $(\mathbf{n}=238)$.

\begin{tabular}{lcccc} 
Variable & Mean & SD & Min-Max & $95 \%$ CI \\
Future anxiety & 38.08 & 21.580 & $0-96$ & $35.33-40.84$ \\
\hline
\end{tabular}

Table 3. Correlation between resilience and future anxiety of Communication and Islamic Broadcasting Department's students at Universitas Ibn Khaldun, Bogor $(n=238)$.

\begin{tabular}{lccc} 
Variable & & Future anxiety & \\
& $\mathbf{N}$ & $\mathbf{r}$ & p-value \\
Resilience & 238 & -0.379 & 0.000 \\
\hline
\end{tabular}


Broadcasting Department students of Universitas Ibn Khaldun. The $r$-value $=-0.379$ indicates a moderate correlation. The minus score indicates a negative correlation direction that means the lower the resilience is, the higher the future anxiety will be and vice versa. Thus, the Ha of this study is accepted.

\section{Discussion}

This study describes that the average age of the Communication and Islamic Broadcasting Department students of Universitas Ibn Khaldun is 20.03 years (95\% CI: 19.84-20.22) with the age ranges are 18 to 26 years old. This result is similar to a research result of Hijrana, who deploys that the students' average score is 20 years old. ${ }^{16}$ Based on this result, it is concluded that all of the respondents are early adulthood.

In this development stage, a person usually will withdraw further from their family, determine career achievement, and decide to marry or have a family. ${ }^{17}$ These tasks probably crate stressors that encourage an individual in early adulthood to encounter psychological disorders, particularly stress and anxiety related to jobs and family. ${ }^{17}$

The majority of Communication and Islamic Broadcasting Department students of Universitas Ibn Khaldun are male, but the difference is slight. This phenomenon agrees with the research by Uriadi, who reveals that the proportion of male and female students in the Communication and Islamic Broadcasting Department of Universitas Islam Negeri is $50 \% .{ }^{18}$ This condition reflects that there is no gender-based tendency in the department. However, the research results by Aliansi Jurnalis Independen (Alliance of Independent Journalists) indicate that in 2016 there were more male journalists than female journalists. ${ }^{19}$

Several other studies conclude that there is no correlation between age and resilience. However, a study by Hamidi reveals that males' resilience is higher than females'. ${ }^{20}$ Males tend to be more resilient in academic fields than females because they have a higher level of stress than males. ${ }^{21}$ Furthermore, a study by Taylor mentions that males and females have different ways to cope with problems, leading females to have lower resilience than males. ${ }^{22}$

Besides, gender can influence an individual's anxiety. Stuart asserts that females are more vulnerable to experience anxiety because their feelings are more sensitive to emotion. ${ }^{23}$ This statement is supported by a study by Hossein and Khazali who discover that females are more vulnerable to have anxiety than males. ${ }^{24}$

Students of class 2019 dominate this study. This result agrees with the 2019 data of Higher Education Database, reporting that the class 2019 has the highest number of students in Communication and Islamic Broadcasting Department students of Universitas Ibn Khaldun. ${ }^{25} \mathrm{~A}$ study by Hammad reveals that finalyear students have the highest level of future anxiety among other years. ${ }^{26}$ Studies by Sheehan and Price indicate that anxiety to face the future commonly occurs in the students of the second or third year ${ }^{26}$. It can be concluded that each academic year potentially to have future anxiety.

Several studies deploy that the correlation between academic year and resilience values is not significant. A study by Fathanah who investigating Bidikmisi scholarship grantees at Universitas Indonesia, reveals that the means of deviation of resilience in each semester is not significant. ${ }^{27}$ This result is supported by the study of Hamidi who asserts that there is no means of deviation in the different academic years. ${ }^{20}$

The majority of research respondents are unmarried, and some of them are married. Individuals' different marital status influences other stressors that lead to mental health problems, such as anxiety.
A study by Vivian, Gesselman, Perry, Fisher, and Garcia discovers that single people have a higher level of anxiety than married people. ${ }^{28}$ The researchers believe that unmarried students feel stronger participatory anxiety because they are thinking about their uncertain status of marriage in the future.

Several previous studies argue several different opinions about the correlation between marital status and resilience. Some of the studies reveal that there is no significant correlation between marital status and resilience. However, Campbell-Sills, Forde, and Stein reveal that there is a correlation between marital status and resilience in which married individuals have higher resilience than divorced or single individuals. ${ }^{29}$

The determination of resilience score is measured by employing the CD-RISC 10 questioner consisting of hardiness dan persistence aspects as the primary dimension that represents resilience. ${ }^{14}$ Hardiness attaches to an individual as a psychological quality that contributes to the achievement of resilience. Many internal or external factors function to trigger the achievement of resilience. However, if the focus is only on the internal factors significantly contributing to resilience, hardiness will be the primary element. ${ }^{30}$ CD-RISC 10 does not have an absolute interval of resilience score to categorize resilience into several levels: low, moderate, or high. Therefore, some studies employing similar questionnaires make the categories and conclude that low resilience is $<34$, moderate is $34-43$, and high is $\geq 44{ }^{31}$ This result reveals that the average resilience score of Communication and Islamic Broadcasting Department students of Universitas Ibn Khaldun is 38.37 and is categorized as moderate resilience.

The level of resilience is different in each group. The score of resilience will be more significant and higher on individuals who experience severe trauma than individuals with minor trauma. ${ }^{14}$ The students of the Communication and Islamic Broadcasting Department of Universitas Ibn Khaldun are described as having no severe trauma disorders because they can still perform their daily activities. Furthermore, this study mentions that the majority of students have a moderate level of stress. ${ }^{32}$ This condition is believed to be a factor that triggers the students to have a moderate score of resilience. A study by Prabowo categorizes resilience scores of CD-RISC 10 and reveals that 42 respondents have a low level of resilience while 45 respondents have a high level of resilience. ${ }^{31}$ Meanwhile, from the results of several studies that reveal students' low level of resilience, it is necessary to perform several efforts to sustainably improve the resilience of Communication and Islamic Broadcasting Department students of Universitas Ibn Khaldun.

Future anxiety is measured using a FAS questionnaire that focuses on the students' anxiety about failure, life difficulties, life goals, failure to provide proper facilities for the family, and fear in the profession..$^{33}$ This research can identify predisposing and precipitating factors based on the results of previous studies. A low level of self-esteem causes predisposing factors in psychological aspects. Furthermore, the predisposing factors of behavior are described by the existence of students' expectations for career and anxiety about job competition. In the external scope, the predisposing factor of behavior is triggered by the alumni's success and the students' friends who raise their anxiety about their future lives. Meanwhile, based on the precipitation factors proposed by Stuart, the students experienced future anxiety because of the self-esteem threats in the form of anxiety about their profession. ${ }^{13}$ Their anxiety was caused by pressures and demands of work in sites, personal problems, or academic problems.

Besides the previously mentioned factors, the occurrence of COVID-19 brings significant impacts on the availability of job opportunities. Central Bureau of Statistics has estimated that the 
number of unemployed will increase in 2020. ${ }^{6}$ The effect also occurs in media as Aliansi Jurnalis Indonesia reports that 23 journalists and media workers have employment issues in some media companies. ${ }^{6}$ This condition results in the occurrence of tougher job competition amidst the increasingly limited availability of job opportunities. Consequently, the students, particularly the Communication and Islamic Broadcasting Department, get more anxious about their future during the pandemic.

Several contributing factors in future anxiety are belief, knowledge, and experience. ${ }^{26}$ Each student has different experiences and expertise related to their preparation for the future. The students of the Communication and Islamic Broadcasting Study Program also experience such a phenomenon. Therefore, the results of this study indicate the diverse levels of future anxiety of each student.

As the FAS questionnaire formulator, Zaleski states that the larger the FAS score is, the more significant future anxiety someone will perceive. ${ }^{15}$ A study by Nadira, who investigated the future anxiety of Psychology Department students of Universitas Indonesia, adapted the FAS questionnaire and categorized the future anxiety into the three scales: below average (low), average (moderate), and above average (high). ${ }^{33}$ Based on the score norms created by Nadira, the researchers found that the average scores of the future anxiety of students of the Communication and Islamic Broadcasting Department of Universitas Ibn Khaldun were in the medium category.

This result agrees with research results by Nadira and Hilmi who investigate the average score of the students' future anxiety. ${ }^{33,34}$ Similar respondents who are students make the results of this research agree with those of the previous studies. The similarities of a survey by Nadira, a survey by Hilmi, and this study can also represent that not only the students of Communication and Islamic Broadcasting experiencing the future anxiety but also students in general. This phenomenon occurs because they are also vulnerable to experience future anxiety. Although the respondents have a moderate level of future anxiety, some show a high score or almost maximal score. This result is necessarily considered serious attention because anxiety can bring negative impacts and potentially disturb daily life. Therefore, the findings indicate that anxiety must be solved.

This research results in statistical analysis on the correlation between resilience and future anxiety to prove the correlation between the two variables. This study agrees with Stuart, who states that resilience is one of the factors determining the anxiety level experienced by someone. ${ }^{13}$ As a protective psychosocial factor, resilience influences the process of regulating emotion in which a person with high resilience will create positive and better emotion. ${ }^{35}$ The process of this regulation has effects on physical and mental health because future anxiety becomes an effector of regulating emotion.

Besides resilience, other factors, such as age, gender, level of knowledge, cultural values, social supports, and marital status, possibly affect the occurrence of anxiety. ${ }^{23,36}$ Students in a particular environment and role have additional factors that can potentially affect their level of anxiety. Hammad states that several factors, such as demands on career achievement, demands on having a family, and uncertainty in the future, make the student experience future anxiety. ${ }^{26}$

The results of this study denoting that a negative relationship between resilience and future anxiety is also supported by Smitas $\&$ Gustainiene. They argued that a low level of anxiety is a result of a high level of resilience. ${ }^{37}$ Meanwhile, the relationship between the two variables is moderate. This condition possibly occurs because resilience is a dynamic psychological construct so that the resilience value is not always stable. ${ }^{38}$
This study has proven that as a variable, resilience negatively correlates to future anxiety and can become a basis for developing resilience enhancement programs and preventing the students' future anxiety. According to Himmel, several actions that can increase the students' resilience are training, resilience skill programs, and stress management. ${ }^{39}$ Meanwhile, Jones, Park, and Lefevor assert that workshops and counseling can become practical tools to improve anxiety management ability, learning skills, and soft skills. ${ }^{40}$ Soft skill improvement is intended to encourage the students' higher levels of self-confidence to face their future.

This study recommends nurses provide health education programs that encourage the increase in resilience. Consequently, the students' future anxiety is solved. Health education programs can be done in training or counseling on stress management. Moreover, higher education institutions are expected to facilitate students by providing counseling and training in time management, enhancing adaptive coping, and developing the alumni association as media of a future planning discussion for students.

Correspondence: Giur Hargiana, Department of Mental Health Nursing, Faculty of Nursing, Jalan Prof. Dr. Bahder Djohan, UI Depok Campus, West Java 16424, Indonesia.

Tel +62.21.78849120 - Fax: +62.21.7864124.

E-mail: giurhargiana@ui.ac.id

Key words: Future anxiety; resilience; students.

Contributions: HM, concept and design, data collector, analysis and interpretation of data, drafting, and manuscript revision; $\mathrm{GH}$, concept and design, analysis and interpretation of data, drafting, manuscript revision.

Conflict of interest: The author have no conflict of interest.

Acknowledgments: The researchers would like to thank the Communication and Islamic Broadcasting of the Faculty of Islamic Studies, Universitas Ibn Khaldun Bogor, who provide the consent to conduct the research. Furthermore, the researchers would like to thank the students of the Communication and Islamic Broadcasting of the Faculty of Islamic Studies, Universitas Ibn Khaldun Bogor, who willingly participated in the research as the respondents.

Ethics approval and consent to participate: The research was approved by the Ethics Committee of Faculty of Nursing, Universitas Indonesia, with number SK-111/UN2.F12.D1.2.1/ETIK2020 on March 11, 2020

Availability of data and materials: The data analyzed are available from the corresponding author on reasonable request.

Conference presentation: This final manuscript has been presented at $7^{\text {th }}$ Virtual Biennial International Nursing Conference, Faculty of Nursing, Universitas Indonesia on September $24^{\text {th }}$, October $30^{\text {th }}$, November $16^{\text {th }} 2020$.

Received for publication: 11 August 2020.

Accepted for publication: 7 May 2021.

oCopyright: the Author(s), 2021

Licensee PAGEPress, Italy

Journal of Public Health Research 2021; $10($ s1):2401

doi:10.4081/jphr.2021.2401

This work is licensed under a Creative Commons Attribution NonCommercial 4.0 License (CC BY-NC 4.0). 


\section{References}

1. Ministry of Health Republic of Indonesia. [Riset kesehatan dasar 2018 (basic health research 2018)].[in Indonesian]. Jakarta: Ministry of Health Republic of Indonesia; 2018. Available from: https://kesmas.kemkes.go.id/assets/upload/ dir_519d41d8cd98f00/files/Hasil-riskesdas-2018_1274.pdf

2. American Psychiatric Association. Americans' overall level of anxiety about health, safety, and finances remain high [Internet]. Washington: American Psychiatric Association; 2019. Available from: https://www.psychiatry.org/ newsroom/news-releases/americans-overall-level-of-anxiety-abouthealth-safety-and-finances-remain-high

3. The American Institute of Stress. Anxiety in college students: causes, statistics \& how universities can help. Weatherford: the American Institute of Stress; 2019. Available from: https://www.stress.org/anxiety-in-college-students-causes-statistics-how-universities-can-help

4. Zaleski Z, Sobol-Kwapinska M, Przepiorka A, Meisner M. Development and validation of the dark future scale. Time Soc 2019;28:107-23.

5. Statistics Indonesia. [Februari 2019, tingkat pengangguran terbuka 5,01 persen (Indonesia's open unemployment rate hits 5.01\% in February 2019)].[in Indonesian]. Jakarta: Statistics Indonesia; 2019. Available from: https://dompukab.bps. go.id/news/2019/05/06/377/februari-2019-tingkat-pengangguran-terbuka-5-01-persen.html

6. Gusman H. [Bagaimana pandemi COVID-19 memengaruhi angka pengangguran RI (how COVID-19 affects to Indonesia's unemployment rates)].[in Indonesian]. Tirto.id; 2020. Available from: https://tirto.id/bagaimana-pandemicovid-19-memengaruhi-angka-pengangguran-ri-fK3e

7. Kelly J. Recent college graduates have the highest unemployment rate in decades - here's why universities are to blame. Forbes; 2019 Nov 14. Available from: http://www.forbes.com/ sites/jackkelly/2019/11/14/recent-college-graduates-have-thehighest-unemployment-rate-in-decadesheres-why-universities-are-to-blame/

8. Usman AR, Bustami, Setiana NA, Hayatullah. [Alumni komunikasi dan penyiaran Islam (KPI): peluang kerja (alumni of islamic communication and broadcasting and job opportunities)].[Article in Indonesian]. Profetik Jurnal Komunikasi 2019; 12:149-59.

9. Ika. [Mahasiswa rentan alami kecemasan sosial (students are likely vurnerable to social anxiety)].[in Indonesian]. Universitas Gadjah Mada; 2019. Available from: https://ugm.ac.id/id/berita/17629-mahasiswa-rentan-alamikecemasan-sosial

10. Collins SPK. Most americans don't know the true danger of anxiety. Think Progress. 2015 Sep 1. Available from: https://archive.thinkprogress.org/most-americans-dont-knowthe-true-danger-of-anxiety-85bc4a08dd2f/

11. Putra W. [Tiga mahasiswa unpad bunuh diri, psikiater ungkap penyebabnya (three students of Padjadjaran University committing mass suicide, a psyhciatric revealed its causes)].[in Indonesian]. Detik News; 2019. Available from: m.detik.com/news/berita-jawa-barat/d-4463416/tiga-mahasiswa-unpad-bunuh-diri-psikiater-ungkap-penyebabnya

12. Videbeck S. Psychiatric-mental health nursing. 5th ed. Lippincott Williams \& Wilkins; 2011.

13. Stuart GW. Princples and practice of psychiatric nursing. 10th ed. Elsevier; 2008.

14. Campbell-Sills L, Stein MB. Psychometric analysis and refinement of the connor-davidson resilience scale (CD-RISC): val- idation of a 10-item measure of resilience. J Trauma Stress 2007;20:1019-28.

15. Zaleski Z. Future anxiety: concept, measurement, and preliminary research. Pers Indiv Differ 1996;21:165-74.

16. Hijrana. Hubungan frekuensi menonton drama Korea dengan perilaku mahasiswa fakultas dakwah dan komunikasi UIN Alauddin Makassar (the correlation between frequency or watching Korean drama with the behavior of students of faculty of da'wa and communication, UIN Alauddin Makassar)].[Thesis in Indonesian]. Makassar: UIN Alauddin Makassar; 2017.

17. Potter PA, Perry AG, Stockert PA, Hall AM. Fundamental of nursing. 8th ed. St. Louis: Elsevier; 2013.

18. Uriadi A. [Respon mahasiswa komunikasi dan penyiaran Islam terhadap program damai Indonesiaku di TV ONE (the communication and da'wa students' responses on damai Indonesiaku TV program airred on TV ONE)].[in Indonesian]. Jakarta: Universitas Islam Negeri Syarif Hidayatullah; 2011.

19. Stellarosa Y, Silaban MW. [Perempuan, media dan profesi jurnalis (women in mass media and journalism)].[Article in Indonesian]. Jurnal Kajian Komunikasi 2019;7:97-109.

20. Hamidi R. [Hubungan optimisme dan resiliensi pada mahasiswa yang menempuh skripsi (the correlation between optimism and resilience on students who do the final paper)].[Thesis in Indonesian]. Malang: Universitas Muhammadiyah Malang; 2017.

21. Prince-Embury S, Saklofske DH, editors. Resilience in children, adolescents, and adults: translating research into practice. New York: Springer; 2012.

22. Cacioppo J, Freberg L. Discovering psychology: the science of mind briever version. Wadsworth: Cengage Learning; 2012.

23. Simanullang MSD. [Faktor-faktor yang memengaruhi tingkat kecemasan diabetisi tipe 2 (Factors affecting the level of anxiety in patient with type 2 diabetes)].[Thesis in Indonesian]. Depok: Universitas Indonesia; 2017.

24. Hosseini L, Khazali H. Comparing the level of anxiety in male \& female school students. Procd Soc Behv 2013;84:41-6.

25. Ministry of Education and Culture, Republic of Indonesia. [Pangkalan data pendidikan tinggi (Higher education database)].[in Indonesian]. Jakarta: Ministry of education and culture Republic of Indonesia; 2020. Available from: https://pddikti.kemdikbud.go.id/

26. Hammad MA. Future anxiety and its relationship to students' attitude toward academic specialization. J Educ Pract 2016;7:54-65.

27. Fathanah. [Hubungan antara resiliensi dan bersyukur pada mahasiswa penerima Bidikmisi di Universitas Indonesia (The relationship between resilience and gratitude among students of University of Indonesia who receive Bidikmisi scholarship)].[in Indonesian]Depok: Universitas Indonesia; 2014.

28. Ta VP, Gesselman AN, Perry BL, et al. Stress of singlehood: marital status, domain-specific stress, and anxiety in a National U.S. Sample. J Soc Clin Psychol 2017;36:461-85.

29. Campbell-Sills L, Forde DR, Stein MB. Demographic and childhood environmental predictors of resilience in a community sample. J Psychiat Res 2009;43:1007-12.

30. Maddi SR. Hardiness turning stressful circumstances into resilient growth. New York: Springer; 2013.

31. Prabowo DA. [Hubungan antara distres psikologis dan resiliensi pada mahasiswa (The relationship between psychological distress and resilience in students)].[Thesis in Indonesian]. Depok: Universitas Indonesia; 2016.

32. Sarini IL. [Hubungan tingkat stres dengan perilaku makan mahasiswa FIK UI saat menjalani praktik klinik di rumah sakit 
(relation between stress level and eating behaviour of nursing student during clinical practice)].[Thesis in Indonesian] Depok: Universitas Indonesia; 2018.

33. Nadira A. [Hubungan antara penerimaan diri dan kecemasan menghadapi masa depan pada mahasiswa Fakultas Psikologi Universitas Indonesia (relationship between the psychology students' self-acceptance to anxiety in facing the future)].[Thesis in Indonesian]. Depok: Universitas Indonsia; 2013.

34. Hilmi MSD. [Kecemasan menghadapi masa depan pada mahasiswa disabilitas (tuna netra) dilihat dari penerimaan diri melalui dukungan sosial di Kota Malang (Anxiety in facing the future in students with disabilities (blind) can be seen from self-acceptance through social support in Malang City)].[Thesis in Indonesian]. Malang: Universitas Islam Negeri Maulana Malik Ibrahim; 2013.

35. Tugade MM, Fredrickson BL, Barret LF. Psychological resilience and positive emotional granularity. J Pers
2004;72:1161-90.

36. Scott KM, Wells JE, Angermayer M, Brugha TS, et al. Gender and the relationship between marital status and first onset of mood, anxiety and substance use disorders. Psychol Med 2010;40:1495-505.

37. Šmitas A, Gustainienė L. Is resilience related to depression, anxiety and energy? European social survey results. Eur Proc Soc Behav Sci 2016;8:125-30.

38. Luthar SS, Cicchetti D, Becker B. The construct of resilience: a critical evaluation and guidelines for future work. Child Dev 2000;71:543-62.

39. Himmel JP. The understanding and promotion of resilience in college students. [PhD Thesis]. New England: Antioch University; 2015.

40. Jones PJ, Park SY, Lefevor GT. Contemporary college student anxiety: the role of academic distress, financial stress, and support. J Coll Couns 2018;21:252-64. 